Article

\title{
Spatial-Temporal Patterns of Bean Crop in Brazil over the Period 1990-2013
}

\author{
Augusto Monso Clemente ${ }^{1}$, Osmar Abílio de Carvalho Júnior ${ }^{2, *}$, Renato Fontes Guimarães ${ }^{2}$, \\ Concepta McManus ${ }^{3}$, Caroline Machado Vasconcelos Turazi ${ }^{1}$ and Potira Meirelles Hermuche ${ }^{2}$ \\ 1 Empresa Brasileira de Pesquisa Agropecuária (EMBRAPA), Parque Estação Biológica, PqEB s/no. \\ Brasília DF 70770-901, Caixa Postal 8605, Brazil; augusto.clemente@embrapa.br (A.M.C.); \\ caroline.turazi@embrapa.br (C.M.V.T.) \\ 2 Departamento de Geografia, Campus Universitário Darcy Ribeiro, Universidade de Brasília (UnB), \\ Asa Norte, Brasília DF 70910-900, Brazil; renatofg@unb.br (R.F.G.); potirahermuche@gmail.com (P.M.H.) \\ 3 Instituto de Ciências Biológicas, Campus Universitário Darcy Ribeiro, Universidade de Brasília (UnB), \\ Asa Norte, Brasília DF CEP 70910-900 Brazil; concepta@unb.br \\ * Correspondence: osmarjr@unb.br; Tel.: +55-61-3107-7264
}

Academic Editors: Tao Cheng, Genong Yu and Wolfgang Kainz

Received: 19 November 2016; Accepted: 19 March 2017; Published: 3 April 2017

\begin{abstract}
The understanding of spatial dependence and distribution of agricultural production factors is a key issue for the territorial planning and regional development. This study evaluates the spatial-temporal dynamics of bean crops in Brazil over the period 1990-2013. Common bean (Phaseolus vulgaris L.) is one of the staple foods for the Brazilian population, with nationwide production and cultivated mostly by family farmers. The analyzed variables of this crop included harvested area, produced quantity, and average crop yield. We investigated spatial autocorrelations using the Global and Local Moran Index. The global spatial autocorrelation statistics demonstrated a general spatial dependence of bean production over Brazil, while the local spatial autocorrelation statistics detect statistically significant zones of high and low bean-production attributes. Maps of growth and acceleration rate of the variables were constructed, showing the areas that increased, decreased, or stagnated during the time series. The results showed a considerable reduction of the bean harvested area, but there were significant increases in produced quantity and average crop yield. Results showed distinct and significant patterns of bean-production variables in Brazilian territory over the different years. Regional differences and peculiarities are evident, emphasizing the need for directing investments to agricultural research and public policy.
\end{abstract}

Keywords: Spatial dependence; Autocorrelation; Cross-tabulation; Phaseolus vulgaris L.

\section{Introduction}

Brazil has 340 million hectares of cultivable area, of which only 63 million are agricultural areas and 200 million hectares are for cattle production [1]. Therefore, around 77 million hectares of the agricultural frontier are still available for use. Furthermore, technological and productivity advancements may release large agricultural and pasture areas for other uses [2].

In Brazil, the estimated grain production in 2014-2015 was 206.3 million tons, considering a planted area of 57.5 million hectares [3]. The estimated production of beans in 2015 was approximately 3.1 million tons, which corresponds to a planted area of 2.9 million hectares and average crop yield of 840,1161 and $2483 \mathrm{~kg} / \mathrm{ha}$ in the 1st, 2nd, and 3rd harvest, respectively [3]. Therefore, this variable showed the highest values in the country's history, an increase of $6.6 \%$ (or 12.7 million tons) compared to the 2013/2014 cycle when it reached 193.62 million tons. 
Although the Brazilian consumer's eating habits are changing, beans are one of the most popular food and a basic dietary component, providing the primary source of vegetable protein [4]. A survey conducted by [5] on eating habits in 10 Brazilian cities found that $94 \%$ of interviewees declared that they frequently eat rice and beans. In Brazil, the average bean consumption per capita is $14.94 \mathrm{~kg} /$ person/year. The bean protein content can reach 33\% with an energy value of $341 \mathrm{cal} / 100 \mathrm{~g}$ [6].

Family farmers are primarily responsible for bean production in Brazil $(70 \%)[7,8]$. This culture is an alternative employment and income source for less skilled workers [9]. Across the country, family farmers with higher financial resources commonly work in cattle and pig farming; while those with fewer resources cultivate corn and bean crops, which have little-added value and are often used for home consumption [10].

In recent decades, establishing spatial-temporal trends of the agricultural expansion to formulate guidelines for regional planning has become a major challenge [11]. Therefore, spatial-temporal analysis provides an opportunity to understand the factors that control agricultural development, contributing to the definition of strategies for resource application and reduction of social and environmental impacts. In this regard, the use of Geographic Information Systems (GIS), Spatial Statistics, and Time Series Analysis has helped in establishing procedures for spatial-temporal data processing.

Spatial statistics deals directly with the effects of spatial dependence and heterogeneity, including methods that incorporate location information such as the geographic coordinates of the site or the polygon of the study region. Agricultural dynamics are spatially-conditioned processes, where the result in one place is affected by events elsewhere. The spatial dependence on the data is responsible for the emergence of spatial patterns, structures, and processes, which can be described through basic functions such as correlograms, variograms, and periodograms [12]. Thus, the primary objectives of an exploratory spatial analysis are to identify and describe spatial patterns, the existence of different spatial regimes or other forms of spatial instability (non-stationarity), atypical observations, and global and local spatial autocorrelation [13]. Among the different spatial analysis methods, one of the most used is the Moran Global Index (I) and the Local Indicators of Spatial Association (LISA) [14].

Time series analysis allow us to analyze the fundamental processes of agricultural production changes and to describe them in quantitative terms, as well as design alternative pathways into the future. Time difference is one of the simplest and most widely used techniques in time series to detect changes [15]. In the analysis of economic and agricultural data, an important time series operator is the growth rate, which is a normalized difference index. Therefore, growth rate is a measure of the percentage change from one period to another. Growth rate represents a first order percentage difference in the sequence of the original data, whereas the growth acceleration represents a second order of differentiation that allows to evaluate the existence of a regional pole with constant growth in time or an isolated event of short duration. Both metrics were applied to understand the dynamics of the regional production of sheep [16] and cattle [17].

The combination of methods that can be used to some extent not only reflect the influence of the spatial pattern but also includes factors of system change. The spatial-temporal distributions of agricultural production have several manifestations according to the producing regions, geographical ordering, spatial dispersion, and the dispute over the growth of agricultural frontiers or the formation of farm belts [18]. Several studies of the temporal-spatial analysis of agricultural products have been carried out in Brazil, mainly at state scale. These include studies of the agricultural production in State of Minas Gerais (MG) during the period 1996-2006 [19]; average coffee productivity in MG (1997-2006) [18]; productivity of the Brazilian agricultural sector (1991-2003) [13]; bean and corn productivity from family farming in the State of Paraná (PR) (2000-2010); canola culture in the PR (2005-2009) [20]; and the soybean production in the PR during the harvests (2003/2004-2007/2008) [21]; and expansion of sugarcane in the State of São Paulo (SP) (1973-2007) [22].

In this study, the aim was to characterize spatial-temporal dynamic of the bean crop in Brazil during the period 1990-2013 using spatial statistical methods and GIS tools. The time series of bean 
production attributes within the Brazilian territory identifies patterns that describe its evolution. Retrospective understanding of the spatial dynamics of bean crop production is crucial to adequate strategies for food security in Brazil.

\section{Methodology}

The digital processing of the agricultural production data of the bean was subdivided into two approaches of regional analysis, considering spatial and temporal metrics (Figure 1). In the first approach was performed a spatial analysis of the municipalities with their neighbors from the spatial autocorrelation using the Moran Global and Local index. In addition, a change detection analysis from the cross tabulation was performed on the time series of Moran Local indices. This procedure allows numerically show the changes in bean production variables over time.

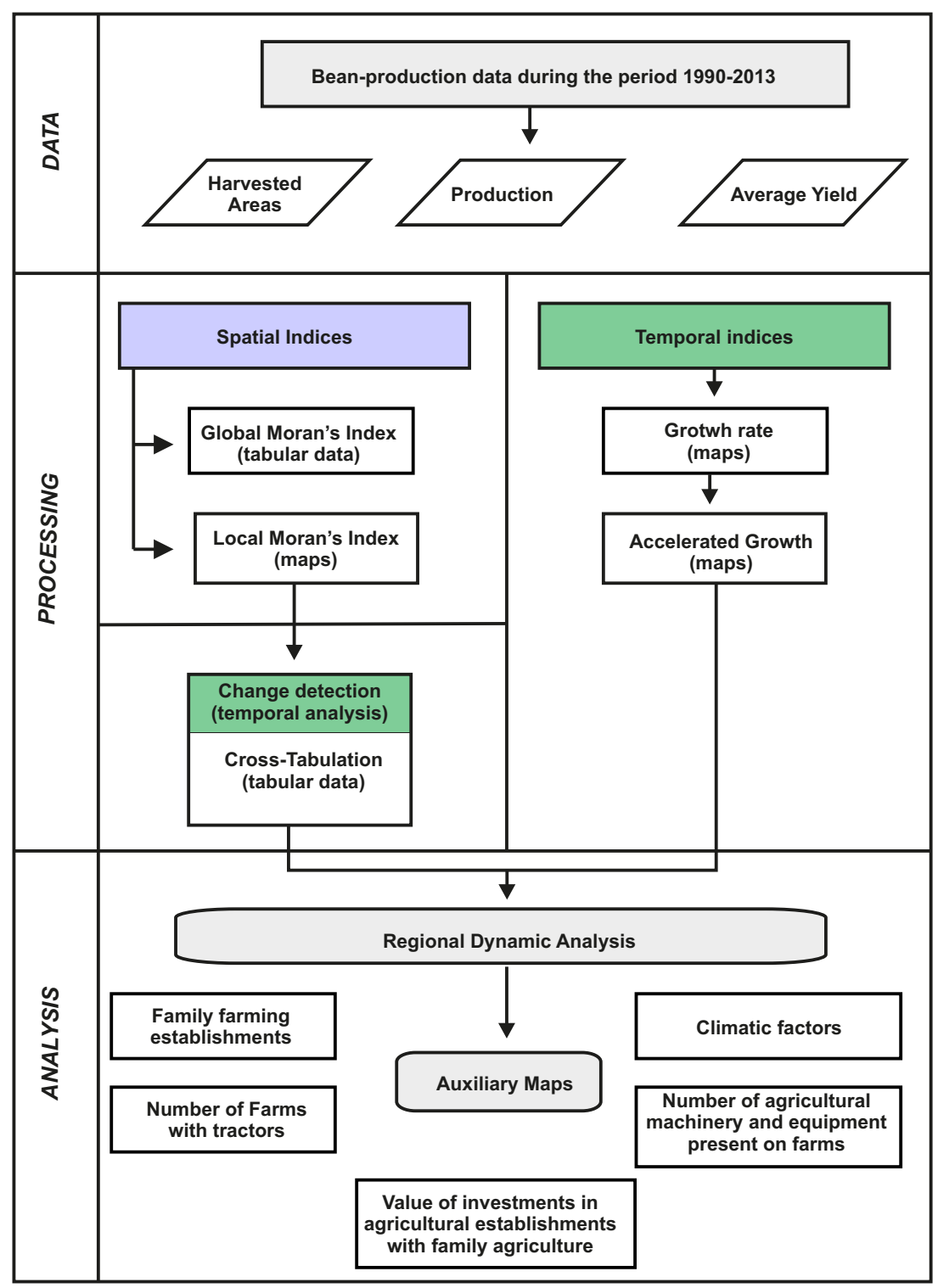

Figure 1. Methodological flowchart of the data processing.

The second approach used the temporal metrics of growth rate and growth acceleration, where municipal data are compared over time. This latter method is widely used in the analysis of economic data. 
Thus, the two approaches were used to identify spatial patterns and highlight trends and change detection of the bean planting. The spatial patterns identified in the two data processing were compared with the data of family establishments and the use of agricultural technology obtained in the last agricultural census carried out in 2006.

\subsection{Municipal Bean-Production Data}

We acquired bean-production data during the period 1990-2013 in the database of Municipal Agricultural Research of the Brazilian Institute of Geography and Statistics (IBGE) (http:/ / www.sidra.ibge.gov.br). In this study, we analyzed three variables related to bean production: (a) harvested area in hectares (ha), which represents the annual total of effectively harvested area in the municipality; (b) produced quantity in tons ( $\mathrm{t}$ ), corresponding to the annual quantity harvested in the municipality; and (c) average crop yield in kilograms per hectare $(\mathrm{kg} / \mathrm{ha})$ described by ratio of the produced amount to harvested area.

We divided the study period into five ranges, where four intervals have five years and the last interval has four years due to the availability of the IBGE data up to 2013. Thus, the intervals analyzed were as follows: 1990-1994, 1995-1999, 2000-2004, 2005-2009, and 2010-2013. The tabulated data containing the arithmetic mean of the variables within the periods for each municipality was linked to spatial vectors of municipalities using ArcGis software package (http:/ /www.esri.com/software/arcgis).

\subsection{Local and Global Moran's Statistics}

Global Moran's I [23] was used to evaluate the spatial autocorrelation of bean production for each reporting period. Global Moran Index is a general measure of spatial autocorrelation between connected areas, which is expressed by (Cliff and Ord, 1981)

$$
I=\frac{n \sum_{i} \sum_{j} w_{i j}\left(x_{i}-\bar{x}\right)\left(x_{j}-\bar{x}\right)}{\left(\sum_{i} \sum_{j} w_{i j}\right) \sum_{i}\left(x_{i}-\bar{x}\right)^{2}},
$$

where " $n$ " is the number of observation; " $x_{i}$ " is the attribute value in the local " $i$ "; " $\bar{x}$ " is the average value of the attribute in the study area; " $w_{i j}$ " are the weight between locations " $i$ " and " $j$." The spatial correlation is calculated only for the municipalities immediate neighbors (first order neighbors), according to the weights " $w_{i j}$ ".

The Moran scatterplot shows the spatial dependence, where the coefficient Moran I is the slope of the regression curve between " $w_{z}$ " and " $z$ " [14,24]. This scatterplot consists of four quadrants: High-High (HH), High-Low (HL), Low-High (LH), and Low-Low (LL), where each quadrant corresponds to a degree of spatial association between a given area and its neighbors, according to weighting matrix (Figure 2).

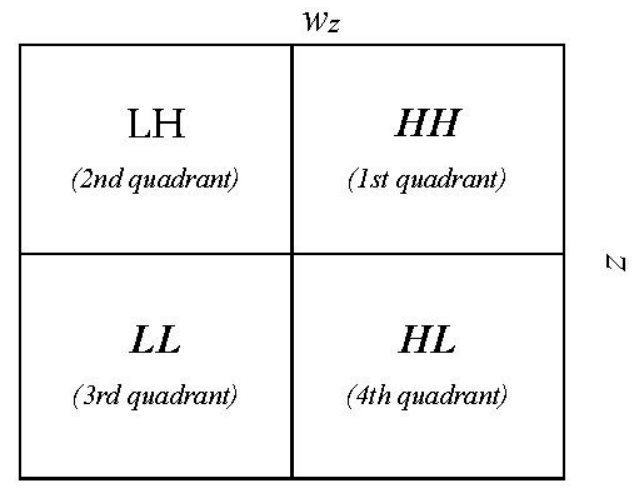

Figure 2. Moran scatterplot. 
The LH quadrant identifies the municipality with lower values than the average for the analyzed variable, which contrasts with their neighbors with higher values than the average. The HL quadrant has high value for the municipality and low values for its neighbors. The LL quadrant has low values for both the municipality and its neighbors. Finally, the HH quadrant has low values for both the municipality and for its neighbors. Therefore, $\mathrm{HH}$ and LL quadrants represent positive autocorrelation, where municipalities and neighbors have similar values. Conversely, HL and LH represent quadrants negative autocorrelation, given that a given area has a low (or high) value, whereas its neighbors are reporting high (or low) values, representing groups with different values [25].

Differently than global measures, local indicators of spatial association (LISA) evaluate the spatial dependence of local patterns. In this context, Local Moran statistics $\left(I_{i}\right)$ aim to make available the patterns surrounding individual observations. This index for observation " $i$ " and its neighbors " $j$ " is defined as [14]

$$
\begin{gathered}
I_{i}=z_{i} \sum_{j} w_{i j} z_{j} \\
I_{i}=\frac{\left(y_{i}-\bar{y}\right) \sum_{j} w_{i j}\left(y_{j}-\bar{y}\right)}{\sum_{i}\left(y_{i}-\bar{y}\right)^{2} / n}
\end{gathered}
$$

where $z_{i}$ and $z_{j}$ are standardized scores, " $w_{i}$ " is spatial weight matrix that defines the spatial structure for the locations included in the calculations of index and the sum $(\Sigma)$ over " $j$ " is such that only the neighbors values of $j \in J_{i}$ are included [14]. This index ranges from 1 to -1 . Positive values demonstrate the presence of spatial autocorrelation with similar values, where a given area and its neighbors are similar [13]. In contrast, negative values imply different behaviors. When the distribution data is random (no spatial correlation), the value Moran is around zero. This index allows the development of maps containing local patterns with similar values that are above the average (hot spot) or below average (cold spot) [26].

\subsection{Cross-Tabulation and Pearson's Chi-Square Test}

The cross-tabulation matrix (also known as confusion matrix, transition matrix, or contingency table) allows a categorical map comparison. This matrix effects a class-by-class paired comparison, which contains the classes of one map as the rows and the classes of the other map as the column. In the temporal analysis, the invariant areas are on the diagonal of the matrix, while the changed areas are positioned off-diagonal. We performed the cross tabulation between the bean variable maps of the first (1990-1994) and the last period (2010-2013) using the Statistical Package for the Social Sciences (SPSS).

The Pearson's chi-square test $(\chi 2)$ identifies if two variables have the same distribution. The test verified the association of agricultural production variables between the periods 1990-1994 and 2010-2013. The $\chi^{2}$ value is expressed by equation

$$
\chi^{2}=\sum_{i=1}^{r} \sum_{j=1}^{c}\left(\frac{O_{i j}-E_{i j}}{E_{i j}}\right)^{2},
$$

where " $O_{i j}$ " and " $E_{i j}$ " are, respectively, the observed and expected frequencies.

\subsection{Analysis of Relative Growth Rate and Accelerated Growth}

In the temporal analysis of bean production variables in Brazil, we elaborated relative growth rate (RGR) and accelerated growth (AG) maps between the different periods analyzed. This methodology has been applied to other types of production, such as cattle [17] and sheep [27]. The RGR value is the percentage change within a period of time, being expressed by the following equation:

$$
R G R=\frac{V_{f-} V_{i}}{V_{i}}
$$


where $V_{i}$ and $V_{f}$ are the initial and final values, respectively. The study period was divided into intervals of five years, except for the last sentence with four years as follows: 1990-1994, 1995-1999, 2000-2004, 2005-2009, and 2010-2013, and the average of each range becomes the value to be analyzed.

The AG is the rate of change of the RGR. In this research, we adopted the RBG difference within a time period, where the $\mathrm{RGR}_{i}$ is the initial value of the time interval and the $\mathrm{RBG}_{f}$ is the final.

$$
\mathrm{AG}=\mathrm{RGR}_{f}-\mathrm{RGR}_{i}
$$

The division by time interval was not applied because it does not change the relation of values among municipalities. We elaborated five maps of growth rate and four AG maps. In this analysis, municipalities with a low value were considered as a non-significant class from the following criteria: less than $200 \mathrm{t}$ bean production, harvested area lower than $200 \mathrm{ha}$ and productivity lower than $400 \mathrm{~kg} / \mathrm{ha}$.

\section{Results}

\subsection{Special Distribution of Agricultural Variables}

Figure 3 shows the spatial distribution of the mean values within the studied years ranges of the agricultural variables (area harvested, quantity produced and average of agricultural productivity). Extensive bean harvesting areas occur in all regions of the Brazilian territory but mainly in the Northeast and Southern region, South Pará (PA), Rondônia (RO), Northwest MG, and the Federal District (FD) and its surroundings. However, the spatial patterns of quantity produced and average productivity become restricted to the west of Bahia, Southern PR, FD, and neighboring municipalities.

\subsection{Global Moran Index Results}

Global Moran indices were greater than zero and $p$-values were less than 0.01 for all variables and periods analyzed. The reliability of $99 \%$ shows the tendency to form clusters of municipalities (Table 1). Furthermore, z-score being inversely proportional to $p$-value confirmed the formation of spatial clusters of bean producers.

Table 1. Global Moran Index for bean production variables in Brazil: harvested area, produced quantity, and average crop yield, considering the periods: 1990-1994, 1995-1999, 2000-2004, 2005-2009, and 2010-2013.

\begin{tabular}{ccccc}
\hline Period & Moran Index & z-Score & $p$-Valor & Result \\
\hline \multicolumn{5}{c}{ Harvested Area (ha) } \\
\hline $1990-1994$ & 0.176640 & 28.952515 & $<0.01$ & Clustered \\
$1995-1999$ & 0.187104 & 30.755577 & $<0.01$ & Clustered \\
$2000-2004$ & 0.162593 & 26.800084 & $<0.01$ & Clustered \\
$2005-2009$ & 0.146992 & 24.340548 & $<0.01$ & Clustered \\
$2010-2013$ & 0.109171 & 18.185954 & $<0.01$ & Clustered \\
\hline \multicolumn{5}{c}{ Produced Quantity (t) } \\
\hline $1990-1994$ & 0.158307 & 26.023559 & $<0.01$ & Clustered \\
$1995-1999$ & 0.124009 & 20.611277 & $<0.01$ & Clustered \\
$2000-2004$ & 0.075855 & 13.132190 & $<0.01$ & Clustered \\
$2005-2009$ & 0.066635 & 11.521104 & $<0.01$ & Clustered \\
$2010-2013$ & 0.058155 & 10.015542 & $<0.01$ & Clustered \\
\hline \multicolumn{5}{c}{ Average Crop Yield (kg/ha) } \\
\hline 1990 a 1994 & 0.304292 & 49.689727 & $<0.01$ & Clustered \\
1995 a 1999 & 0.355420 & 58.041867 & $<0.01$ & Clustered \\
2000 a 2004 & 0.438927 & 71.662111 & $<0.01$ & Clustered \\
2005 a 2009 & 0.438927 & 71.662111 & $<0.01$ & Clustered \\
2010 a 2013 & 0.504050 & 82.284857 & $<0.01$ & Clustered \\
\hline
\end{tabular}




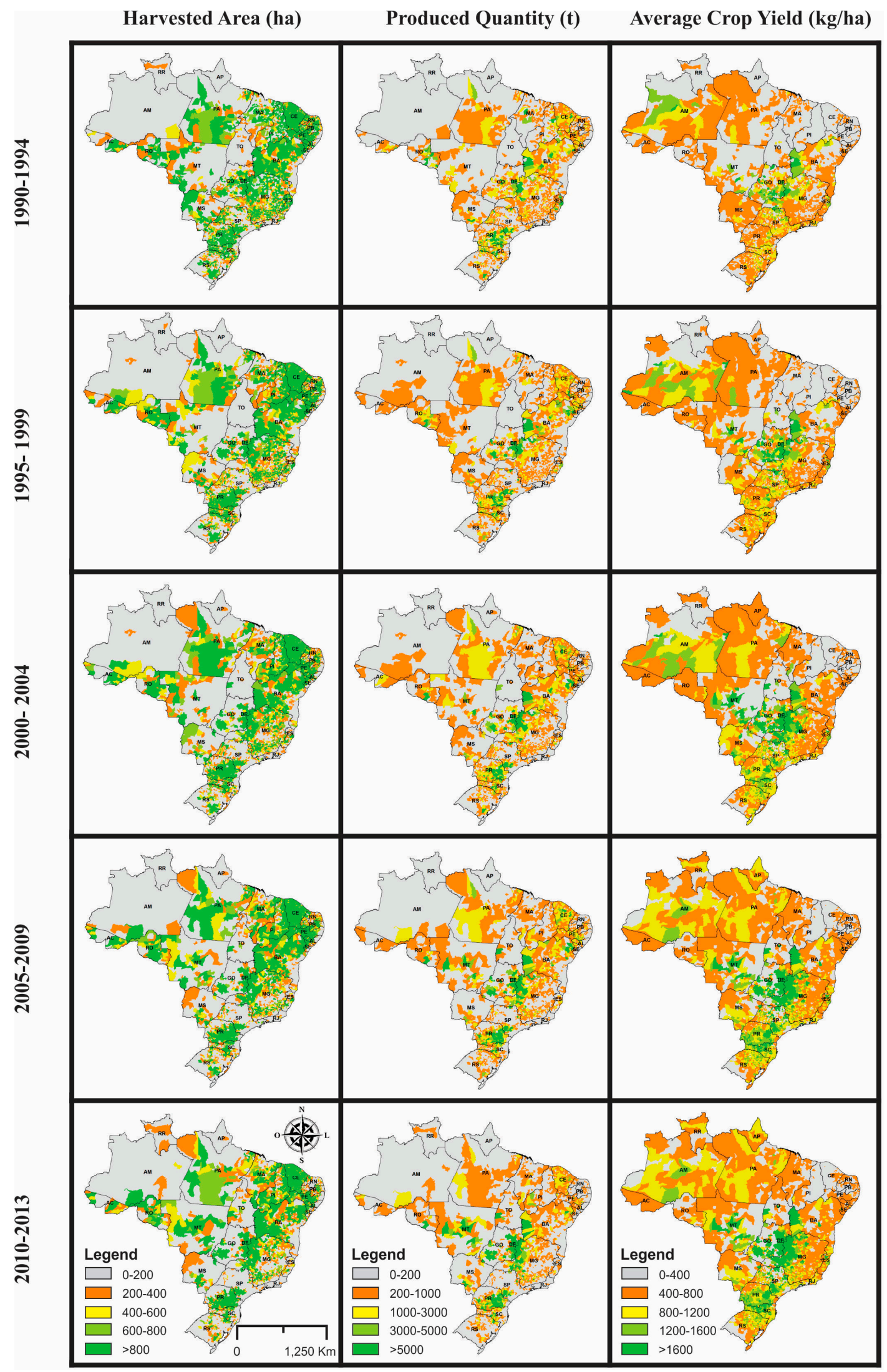

Figure 3. Bean production maps: Harvested area (ha), Produced Quantity (t), Average Crop Yield (kg/ha), considering the periods: 1990-1994, 1995-1999, 2000-2004, 2005-2009, and 2010-2013. 
Figure 4 presents LISA maps of analyzed variables (harvested area, produced quantity, and average crop yield) over the study period. The autocorrelation analysis providing sufficient spatially aggregated insights into the location of bean production. Therefore, the local autocorrelation maps demonstrate and synthesize the main agglomerations of the bean production variables and highlight regional differences.

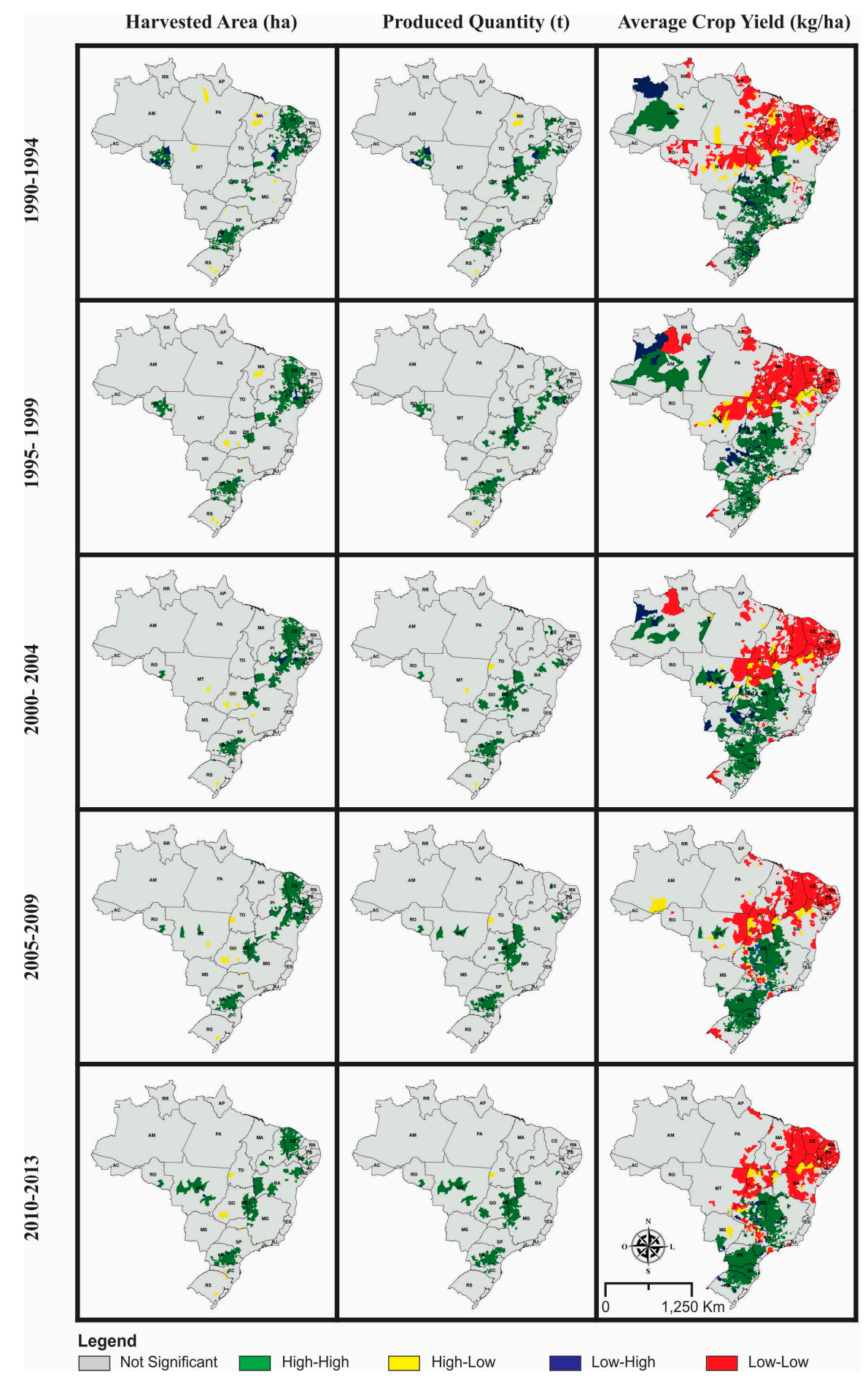

Figure 4. Moran Local Index maps of bean production attributes: Harvested area (ha), Produced Quantity (t), Average Crop Yield (kg/ha), considering the periods: 1990-1994, 1995-1999, 2000-2004, 2005-2009, and 2010-2013. 
Harvested area of bean had stable $\mathrm{HH}$ groups in all study periods for the Central-East PR, Southern SP, Northwest MG, around the FD, and different places of the Northeast region, Ceará (CE), Paraíba (PB), Pernambuco (PE), Alagoas (AL) and Sergipe (SE). Some LH groups with low representation appeared in Rondônia (RO), Bahia (BA), Piauí (PI) and Paraná (PR) (1990-1994); BA, PE, and PR (1995-1999); BA and PR (2000-2004 and 2005-2009); and BA, PR, and Mato Grosso (MT) (2010-2013). The HL class was distributed in the following states: Pará (PA) (1990-1994), MG (1990-1994, 2000-2004, 2005-2009 and 2010-213), Tocantins (TO) (2005-2009 and 2010-213), Maranhão (MA) (1990-1994 and 1995-1999), Goiás (GO) (all periods), MT (all periods), SP (all periods), and Rio Grande do Sul (RS) (all periods). Between 1990-1999 and 2000-2004, the HH group in RO reduced to only two municipalities (Alta Floresta do Oeste and Alto Alegre dos Parecis). In MT, an HH cluster developed over the period 2010-2013, being composed of the municipalities Tabaporã, Primavera do Leste, and Nova Ubiratã. Municipalities considered not significant have different values of harvested area compared to their neighboring municipalities.

The produced quantity showed a hot-spot zone (composed of $\mathrm{HH}$ stable groups throughout the study period) in the Central-East PR, South of SP and some regions in Central SC. Some areas of HH clusters have become consolidated over the studied period such as municipalities in Northwest MG, Central-Eastern and Southwest GO, FD and surrounding area, Central and Southeast MT, and Western BA (Barreiras and Luís Eduardo Magalhães). In the Northeast region, some HH groups displaced throughout the years, reaching a peak in the periods 1990-1994 and 1995-1999. In the period 2010-2013, the bean producing municipalities concentrated in the region of São Desidério and Euclides da Cunha (BA). In RO, the HH cluster in periods 1990-1994 and 1995-1999 showed a decrease in 2000-2004, being restricted to the municipalities of Alta Floresta do Oeste and Alto Alegre dos Parecis. CE showed oscillations, starting from 1990-1994 consolidated in 1995-1999, but intensely decreased in 2000-2004.

LISA maps for the bean average crop yield in the studied periods obtained the following results: (A) consolidation of $\mathrm{HH}$ clusters (hot spots) especially in PR, SC, GO, MG, RS, and South SP; (B) concentration of LL clusters (cold spots) in Northeast region, North region (mainly TO) and West Central region (East MT and Central-North GO); and (C) occurrence of HL clusters (outliers) in the Sao Desidério and Euclides da Cunha (BA), Central and Northern GO, Central Mato Grosso do Sul (MS), and East MT.

The Amazon region has a distinct behavior about other bean production variables. In the periods 1990-1994 and 1995-1999, there were some HH clusters scattered in the Amazonas (AM) and Roraima (RR) that remained until the period 2000-2004. However, for the other variables (production and harvested area), this information was not relevant. Therefore, these municipalities produced few beans in small areas, but with a large average crop yield $(\mathrm{kg} / \mathrm{hectare})$, allowing the formation of groups. These groups gradually disappeared, ceasing from 2005 to 2009.

\subsection{Cross-Tabulation and $\chi^{2}$ Results}

The cross-tabulation detected changes of LISA clusters (HH, HL, LH, and LL) for the bean-production variables between the average values of the period 1990-1994 and 2010-2013 (Table 2). The harvested area showed 430 municipalities with HH class in 1990-1994, of which only 207 remained in the same classification in 2010-2013, and 136 new municipalities reached the HH class, totaling 343 municipalities in the last period. HL class had 13 municipalities in the first period and nine remained in last period. LH class had 46 municipalities in 1990-1994, remaining four municipalities in the last period. The number of non-significant municipalities increased from 5075 (1990-1994) to 5208 (2010-2013). 
Table 2. Cross Tabulation of the LISA classes for bean planting variables (harvested area, produced quantity, and average yield) between the periods 1990-1994 and 2010-2013.

\begin{tabular}{|c|c|c|c|c|c|c|c|}
\hline & & \multicolumn{6}{|c|}{ Harvested Area (ha)—(2010-2013) } \\
\hline & & Not Significant & $\mathbf{H H}$ & HL & LH & LL & Total \\
\hline \multirow{7}{*}{$\begin{array}{l}\text { Harvested area (ha) } \\
\quad(1990-1994)\end{array}$} & Not Significant & 4938 & 128 & 6 & 3 & & 5075 \\
\hline & HH & 222 & 207 & 1 & 0 & & 430 \\
\hline & HL & 11 & 0 & 2 & 0 & & 13 \\
\hline & LH & 37 & 8 & 0 & 1 & & 46 \\
\hline & Total & 5208 & 343 & 9 & 4 & 0 & 5564 \\
\hline & & \multicolumn{6}{|c|}{ Produced Quantity (t)—(2010-2013) } \\
\hline & & Not Significant & $\mathbf{H H}$ & HL & LH & LL & Total \\
\hline \multirow{7}{*}{$\begin{array}{l}\text { Produced Quantity (t) } \\
\quad(1990-1994)\end{array}$} & Not Significant & 5143 & 62 & 1 & & & 5206 \\
\hline & HH & 205 & 108 & 0 & & & 313 \\
\hline & HL & 6 & 0 & 0 & & & 6 \\
\hline & LH & 29 & 10 & 0 & & & 39 \\
\hline & Total & 5383 & 180 & 1 & & & 5564 \\
\hline & & \multicolumn{6}{|c|}{ Average Crop Yield (kg/ha)—(2010-2013) } \\
\hline & & Not Significant & $\mathbf{H H}$ & HL & LH & LL & Total \\
\hline \multirow{6}{*}{$\begin{array}{c}\text { Average Crop Yield (kg/ha) } \\
\text { (1990-1994) }\end{array}$} & Not Significant & 2151 & 534 & 18 & 38 & 617 & 3358 \\
\hline & HH & 340 & 514 & 18 & 26 & 37 & 935 \\
\hline & HL & 29 & 1 & 9 & 0 & 15 & 54 \\
\hline & LH & 95 & 78 & 3 & 15 & 24 & 215 \\
\hline & LL & 343 & 0 & 10 & 0 & 649 & 1002 \\
\hline & Total & 2958 & 1127 & 58 & 79 & 1342 & 5564 \\
\hline
\end{tabular}

The produced-quantity variable presented 313 municipalities as HH class in 1990-1994, of which 108 remained in the same classification in the period 2010-2013, from a total of 180 municipalities. HL class decreased from 6 municipalities to only one between the periods, and LH class from 39 to none. The number of municipalities that do not fall into any class (HH, HL, LH, LL) is 5206 (1990-1994) and 5383 (2010 to 2013).

The average crop yield variable increased HH class from 935 municipalities (1990-1994) to 1127 municipalities (2010-2013). HL class changed between the two periods of 54 to 58 municipalities, while LH class from 215 to 79 municipalities. The number of municipalities that did not fit in any group was 3358 (1990 to 1994) and 2958 (2010-2013), i.e., a reduction of approximately 12\%.

The $\chi^{2}$ results of bean production variables: harvested area (1653.469 with 9 degrees of freedom for a $95 \%$ confidence level), produced quantity (1109.931 with 6 degrees of freedom for a 95\% confidence level) and average crop yield (2145.661 with 16 degrees of freedom at the $95 \%$ confidence level) show $p=0.000(p<0.05)$. These values indicate that there is a correlation between the data of 1990-1994 and 2010-2013. Therefore, the spatial distribution did not change significantly between the two periods.

\subsection{Results of Relative Growth Rate and Accelerated Growth Maps}

Figure 5 shows the Brazilian municipalities that achieved growth, stagnation, or reduction for bean planting variables for the period 1990-2013. Some decreased or stagnated in the bean harvested areas, such as in the following states: MT, Piauí (PI), PA, AM, MA, TO, and SP. The municipalities with the continued growth of the harvested area are scattered in several states, but the highest intensity occurs in the North and West Central regions, especially in MT.

The produced quantity increased in most municipalities, mainly in the following states: AM, MT, MS, RR, PA, MA PI, BA, MG, GO, FD, and PR. Stagnant production areas concentrated in the West Central Region (MT and GO), North region (AM and PA), as well as TO and SP. Municipalities with area reduction for all periods are spread over several states, highlighting located in the Southeast and Northeast regions. 


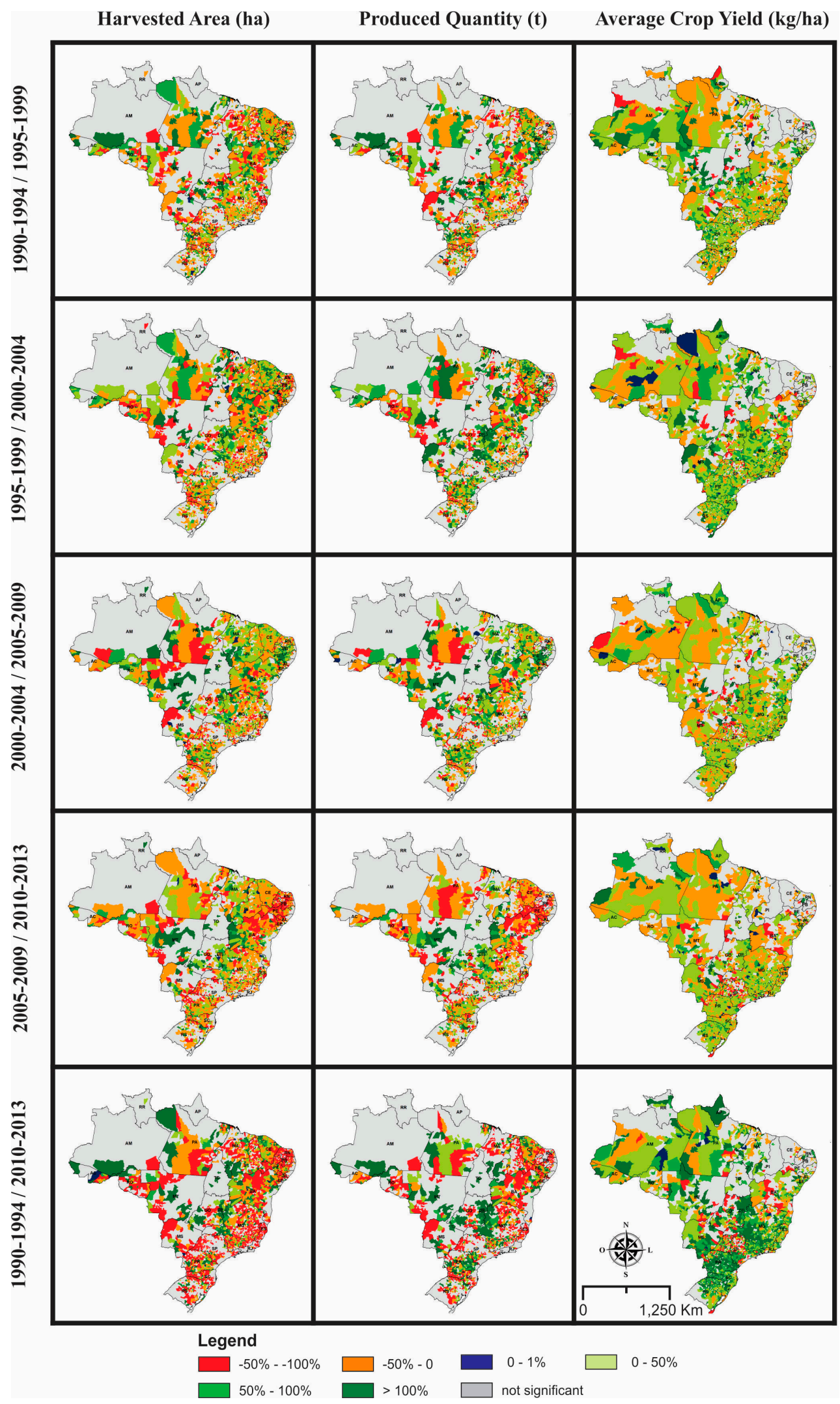

Figure 5. Growth rate maps of the following bean planting variables: harvested area (ha), produced quantity (t), and Average Crop Yield (kg/ha), considering the periods: 1990-1994/1995-1999, 1995-1999/2000-2004, 2000-2004/2005-2009, 2005-2009/2010-2013, and 1990-1994/2010-2013. 
Most municipalities showed an increase in growth rates of bean productivity, highlighting the following states: MG, SC, GO, FD, and the Southern Region. The areas without growth in bean productivity are mostly located in the Midwest region (MT and GO), North region (AM and PA), as well as TO, PI, MA, and SP. Municipalities that showed the greatest decrease in crop yield were located in the Northeast region.

Figure 6 shows the AG maps to the bean variables in the studied periods, including the comparison between 1990-1999 and 2005-2013. The accelerated rate of harvested area was intense in the following states of MT, MA, PI, GO, TO and BA (Barreiras and Luís Eduardo Magalhães). The invariant municipalities in the studied periods concentrated largely in MT, TO, GO, SP, and MG.

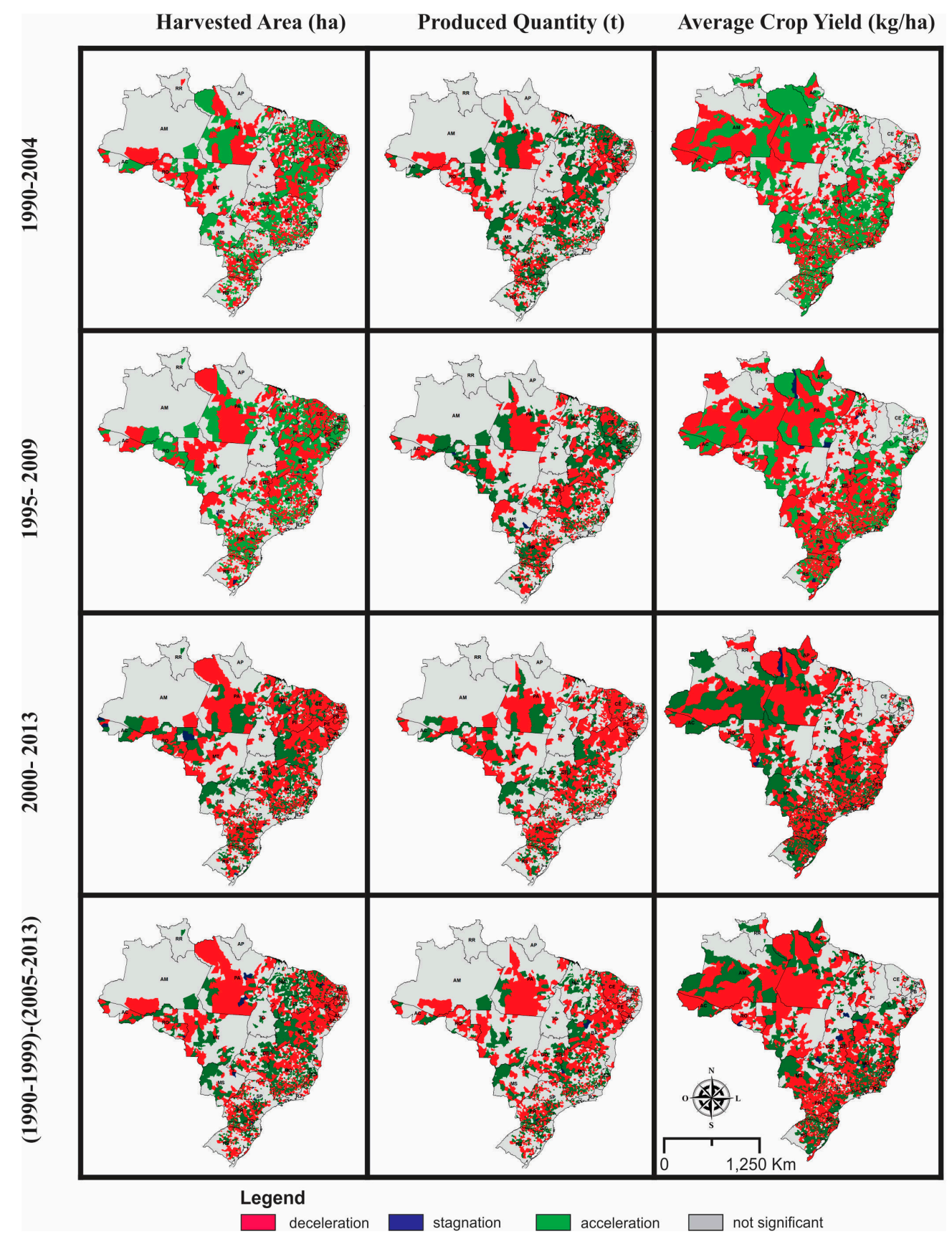

Figure 6. Accelerated growth maps of the following bean planting variables: harvested area (ha), produced quantity (t), and Average Crop Yield (kg/ha), considering the periods 1990-2004, 1995-2009, 2000-20013, and (1990-1999)-(2005-2013). 
The bean produced quantity showed higher acceleration in MT, MA, PI, GO, and TO. BA had several municipalities with growth accelerating in the 1990-2004 period, while PE in the period 1995-2009. The decrease occurred in the South (especially in PR), Southeast (except MG), North, and Northeast (especially CE).

The average crop yield had positive values of AG in the municipalities of MG, PA, BA, MA PB, PE, BA, RN, Western PI, and Southern Region (PR, RS and SC). In other regions, decelerating growth is predominant. Municipalities stagnant in average crop yield show a gradual increase in comparison to the average crop yield mainly located in the Central West Region, North, BA, PI, TO, MG, and SP.

\section{Discussion}

In the political decision-making process for regional development, the identification of spatial patterns of production, and their performance over time are fundamental. Space-time analysis using Geographic Information System for investigations of agricultural production is extremely useful for the discretization of economic regions and the definition of guidelines for development. Agglomerations and spatial interdependencies between economies is a key factor in stimulating regional development and generate increasing returns [28]. The spatial autocorrelation detection highlights the spatial structure and aggregation levels of the producing regions. Therefore, different surveys have used spatial variation techniques for the analysis of agricultural productivity [29-32].

Brazil is currently the largest producer and consumer of common beans in the world [33]. Bean planting in a single or intercropping system with other cultures occurs throughout the Brazilian territory. In this study, the combination of various methods of spatial-temporal analysis enables to demonstrate a high dynamic of the bean production in Brazilian municipalities between 1990 and 2013. We choose the Moran's Index because it is the most popular procedure for spatial dependencies, being applied in many research areas [34]. Besides, growth and acceleration rates are widely used for measuring percentage change of economic variables over time [35].

The application of Local Moran statistic to bean production data verified distinct spatial patterns in Brazilian territory along the temporal series, highlighting hot and cold spots for bean variables. In addition, the RGR and AG show the places with temporal changes relating to the bean-production variables.

The top five bean producing states were PR, MG, BA, GO, and SP. Local Moran Index of bean harvested area during the period 1990-2013 indicates a greater concentration of productive municipalities in the South, West-Central, and Northeast regions of Brazil. Despite the fact that the average bean yield of the bean increased from $477(\mathrm{~kg} / \mathrm{ha})$ in 1990 to $1028(\mathrm{~kg} / \mathrm{ha})$ in 2013, the spatial distribution of this attribute shows marked differences between Brazilian regions. In the South and Center-West, there is a concentration of HH clusters, contrasting with the Northeast region, where the LL groups predominate. Therefore, Northeast region has the largest harvested area in the country but has lower productivity. This characteristic is also evidenced in the maps that compare the growth rates of produced quantity and average crop yield in Brazil between the periods of 1990-1994 and 2010-2013. This productivity difference also occurred locally in the South and West Central regions, where some municipalities reach productivity values of about $3 \mathrm{t} / \mathrm{ha}$ while others no more than $200 \mathrm{~kg} / \mathrm{ha}$, similar values to some Northeastern municipalities.

The formation and growth of producing areas are driven by different stimuli. Therefore, regional differences have a multifaceted occurrence that encompasses various inequalities, considering environmental factors, historical activities, technology, production capacity, local demand for the product, infrastructure, and government funding, and there is not a single comprehensive factor to evaluate its various dimensions. These issues of regional development have locally specific overlapping causes, considering environmental, socioeconomic, and political activism.

A strong natural limitation for the agricultural production by small farmer of the Northeast region is the low rainfall over an extended period. Figure 7 shows the spatial distribution of the following climatic factors compiled by [27] average rainfall from 2000 to 2010 using the image sensor TRMM 
(Tropical Rainfall Measuring Mission), average surface temperature data of the period 2000-2011 from the MODIS Land Surface Temperature and Emissivity (MOD11 product), and average relative humidity data from a range of approximately 30 years of observations considering 283 weather stations distributed throughout the territory from the National Institute of Meteorology (INMET). The Northeast region presents the lowest values of average precipitation and relative humidity and has high values of temperature.
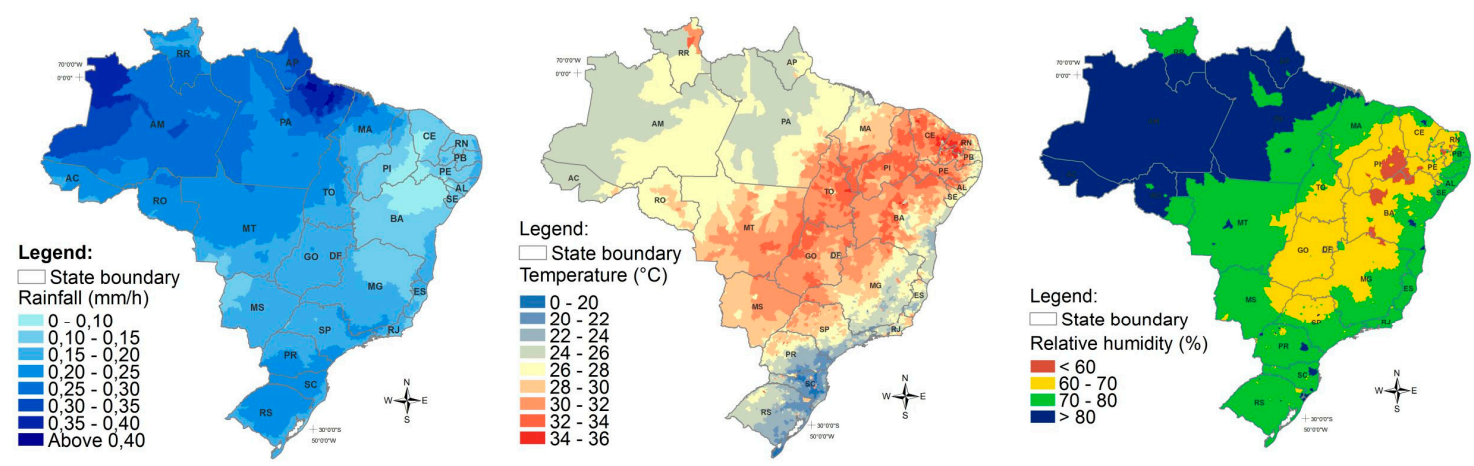

Figure 7. Maps of average rainfall from 2000 to 2010 (left) average surface temperature data of the period 2000-2011 (middle); and average relative humidity from a range of approximately 30 years of observations (right).

In addition to the climatic factor, the adoption of inappropriate management practices and the lack of technology and agricultural machinery lead to a decline in productivity [36]. In the absence of adequate information on the specific characteristics of bean production, we examined the last census of Brazilian agriculture for the year 2006 developed by a collaboration between the Ministry of Agrarian Development and Brazilian Institute of Geography and Statistics (IBGE, 2009). Figure 8 shows maps referring to the 2006 census of agriculture: percentage of family farming establishments over the total number of agricultural establishments in the municipalities, number of agricultural establishments with tractors, number of machines and agricultural implements existing in establishments, and values of investments in establishments with family agriculture. In the 2006 census survey, the terminology "family farming" is related to the family unit, while the "establishment" corresponds to the productive unit. Figure 8A shows a predominance of family agriculture in the Brazilian territory, corresponding to $84 \%$ of agricultural establishments $(4,367,902$ establishments in relation to the total of $5,175,489)$. The lowest percentage of family farms occurs in the municipalities of SP, MG, GO and MS. However, the behavior is reversed considering the area occupied by family farms ( $24 \%$ of area establishment), which reveals an unequal distribution of land.

Figure $8 \mathrm{~B}, \mathrm{C}$ show regionally the presence of agricultural equipment in the establishments, indicating the presence of a larger technological apparatus and an improvement in productivity. These attributes show a higher concentration in the Southeast, Center-West, and Southern regions of Brazil, which contrasts with the North and Northeast regions. In the Northeast region, the Western Bahia presents a distinct behavior due to the development of agribusiness that uses highly intensive farming systems $[37,38])$.

Despite beans being considered subsistence farming, they are also grown in production systems that use intensive technologies such as irrigation, pest control, and agricultural machinery [39]. According to Barreto and Almeida, [40], the increase in productivity and spatial changes are the results of investments in agricultural research. The new producing regions increase in crop yield is due to the adoption of measures to increase the production capacity, such as irrigation, winter crops, genetic improvement of the species, development of beans cultivars suitable for growing in different environments, and advances in the control of pests and diseases [39,41]. While some farmers use modern techniques of planting, the vast majority are family farming that persists in the traditional 
manner. Although there is the availability of an extensive inventory of technologies for the cultivation of beans, there are still knowledge gaps and the lack of an efficient technology transfer for the family farmer [42].
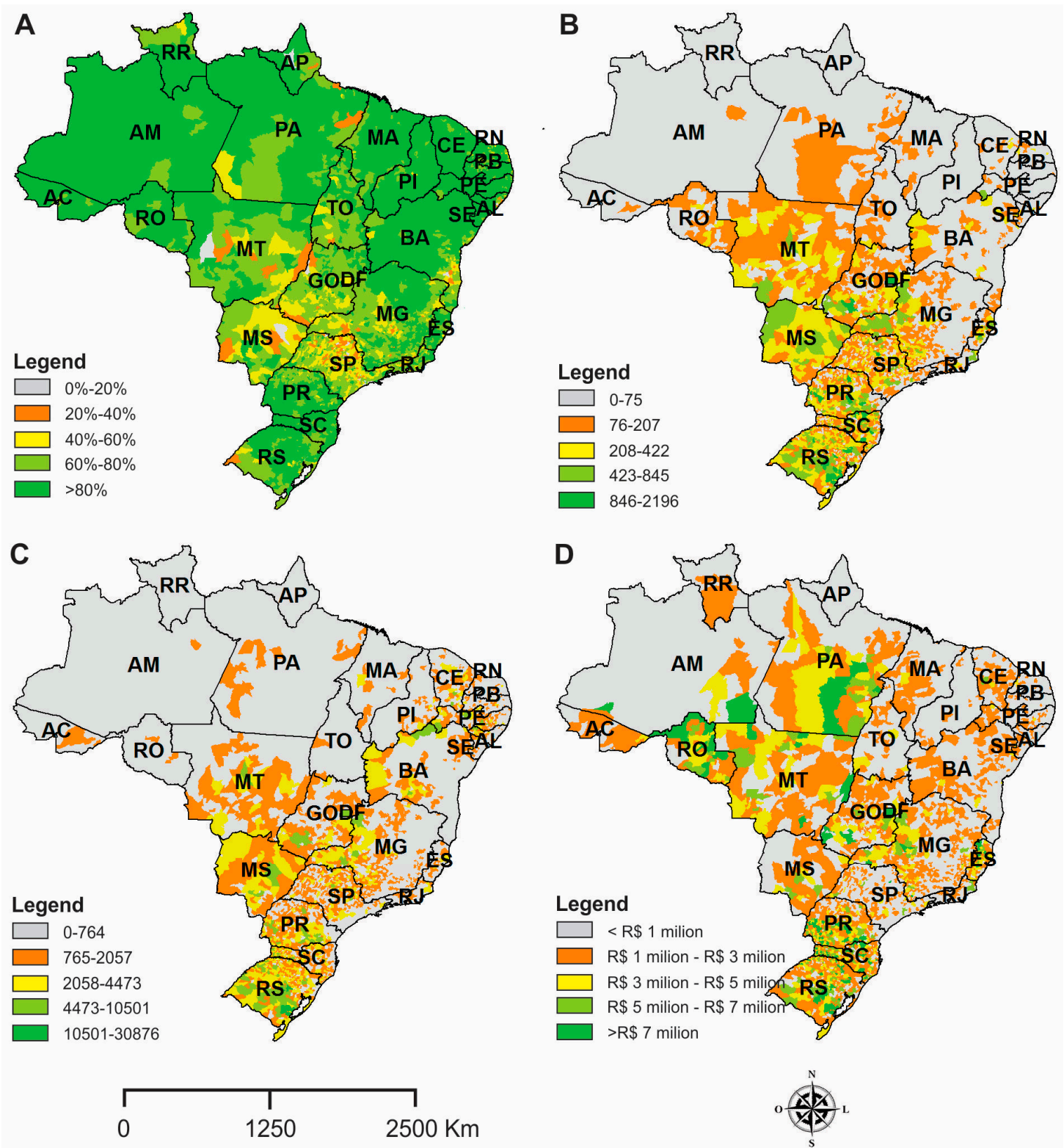

Figure 8. Maps of 2006 Brazilian census of agriculture: (A) percentage of family farming establishments over the total number of agricultural establishments in the municipalities; (B) number of agricultural establishments with tractors; (C) number of machines and agricultural implements existing in establishments; and (D) values of investments in establishments with family agriculture (R\$).

Figure 8D shows that the largest investments for family farmers occurred mainly in the South region, around the Federal District (including MG and GO) and Northern MT. These sites correspond to the areas with the highest average crop yield of bean along the time series. Therefore, large clusters of bean area in the Northeast region are composed of family farmers, in which much of the production is for self-household consumption and deprived of technical support and low technological levels [7]. These low input agricultural systems with predominance of subsistence agriculture are currently located in marginal areas with little natural aptitude for agricultural mainly due to less favorable climatic conditions. 
However, family farmers are responsible for approximately $70 \%$ of bean production in Brazil, having a decisive role in the production chain. Bean crop showed a decrease in its harvested area of about $40 \%$, from 4,680,094 (ha) in 1990 to 2,813,506 (ha) in 2013, releasing in this period an area of $1,866,588$ hectares to other crops (mainly soybeans). According to [43], expansion of the harvested area in most temporary crops (except soybeans) was insignificant, and in many cases there was a reduction, as happened with the beans. Recently, the high cost of production and low prices offered to bean producers discourages planting. Consequently, support for bean crops should be expanded with actions to increase investment in research, technology transfer, and infrastructure for storage and distribution to put small farmers in the production system and ensure their livelihood.

The results may also reflect the differences in seasonal production systems throughout the year, an important topic to be verified in future works. The rainy season beans (1st harvest) have the highest productivity, as opposed to dry season beans (2nd harvest), while the winter beans (3rd harvest) may suffer from dry period risks, but can achieve high productivity if the crops make use of irrigation and a high technological level.

\section{Conclusions}

Although in general terms the bean harvested area in Brazil has developed very slowly or even decreased throughout the period 1990-2013, the produced quantity and average crop yield showed an increasing trend over the years. However, the bean-production dynamic showed different patterns, which makes it difficult to propose a single national model.

LISA maps show evidence of regional differences, where the Northeast Region has an entirely distinct behavior compared to the Central and South Regions. The Northeast has LL groups for average crop yield and $\mathrm{HH}$ groups for harvested area over time, while the South and Southeast have HH groups for both variables. These spatial correlations of bean production variables show evidence of economies of scale, which not only emphasizes productivity and growth but also reinforces the potential of Central and South regions as main attraction points for additional technological applications and improvement of the bean production chain. The Northeast region is composed mainly of family farmers with low technological improvements.

The growth rate and accelerated growth maps also show evidence of distinct regional behaviors, despite these being constituted by more fragmented patterns. The harvested areas decreased through time in most of the territory, while average crop yield tends to increase in the southeast, south, and central regions. These maps also show bean production areas in the North and Central West, which are isolated municipalities and not detected in LISA maps.

Apparently, the spatial distribution of bean production expresses the socio-economic conditions of Brazilian regions. Strategies for the growth of bean production should consider the regional characteristics of farmers and their technological levels. The Northeast region needs an efficient technology transfer from an active role of government actors to improve the efficiency and profitability of local producers. Therefore, a major challenge is to establish regional strategies to enable low-income family farmers to produce more.

Acknowledgments: The authors wish to acknowledge the contribution and scientific support for Empresa Brasileira de Pesquisa Agropecurária (EMBRAPA) and Conselho Nacional de Desenvolvimento Científico e Tecnológico (CNPq) for research grants.

Author Contributions: Augusto Clemente and Osmar Abílio de Carvalho Júnior conducted the work, conceived the idea, and were responsible for the acquisition, analysis and interpretation data. Caroline Turazi made substantial contributions. Renato Fontes Guimarães, Potira Meirelles Hermuche, and Concepta McManus supported acquisition, analysis, and critically revised the work for fundamental intellectual content. All authors edited and reviewed the paper.

Conflicts of Interest: The authors declare no conflict of interest. 


\section{References}

1. Wilkinson, J. The globalization of agribusiness and developing world food systems. Mon. Rev. 2009, 61, 38-49. [CrossRef]

2. Wilkinson, J. Transformações e perspectivas dos agronegócios brasileiros. Rev. Bras. Zootec. 2010, 39, 26 -34. [CrossRef]

3. Companhia Nacional de Abastecimento. CONAB Acompanhamento da Safra Brasileira de Grãos; Companhia Nacional de Abastecimento: Brasília-DF, Brazil, 2013.

4. Reinaldo, E.D.F.; Da Silva, M.R.F.; Nardoto, G.B.; Garavello, M.E.P.E. Mudanças de hábitos alimentares em comunidades rurais do semiárido da região nordeste do Brasil. Interciencia 2015, 40, 330-336.

5. Barbosa, L. Feijão com arroz e arroz com feijão: O Brasil no prato dos brasileiros. Horiz. Antropol. 2007, 13, 87-116. [CrossRef]

6. Pompeu, A.S. Melhoramento do feijoeiro (Phaseolus vulgaris L.). In Feijão_Fatores de Produção e Qualidade; Bulisani, E.A., Ed.; Fundação Cargill: Campinas, Brazil, 1987.

7. Silva, O.F.; Wander, A.E. O feijão-comum no Brasil: Passado, presente e futuro. Embrapa Arroz e Feijão 2013, 287, 1-63.

8. Mattei, L. O Papel e a importância da agricultura familiar no desenvolvimento rural brasileiro contemporâneo. Rev. Econ. Nord. 2014, 45, 83-91.

9. Carneiro, P.T.; Parré, J.L. A importância do setor varejista na comercialização de feijão no Paraná. Rev. Econ. Agronegócio 2005, 3, 277-298.

10. Guanziroli, C.; Romeiro, A.; Buainain, A.M.; Sabbato, A.D.; Bittencourt, G. Agricultura Familiar e Reforma Agrária no Século XXI; Garamond: Rio de Janeiro, Brazil, 2001.

11. Freitas, R.E.; Mendonça, M.A.A.; Lopes, G.d.O. Expansão de área agrícola: Perfil e desigualdade entre as mesorregiões brasileiras. Texto Para Discuss. Inst. Pesqui. Econ. Apl. 2014, 1926, 1-45.

12. Gould, P. Is statistix inferens the geographical name for a wild goose? Econ. Geogr. 1970, 46, 439-448. [CrossRef]

13. Perobelli, F.S.; de Almeida, E.S.; da Silva, A.; Alvim, M.I.; Ferreira, P.G.C. Produtividade do setor agrícola brasileiro (1991-2003): Uma análise espacial. Nov. Econ. 2007, 17, 65-91. [CrossRef]

14. Anselin, L. Local Indicators of Spatial Association-LISA. Geogr. Anal. 1995, 27, 93-115. [CrossRef]

15. Lu, D.; Mausel, P.; Brondizio, E.; Moran, E.F. Change detection techniques. Int. J. Remote Sens. 2004, 25, 2365-2407. [CrossRef]

16. Hermuche, P.; Guimarães, R.F.; Carvalho, O.A.; Gomes, R.A.T.; Paiva, S.R.; McManus, C.M. Environmental factors that affect sheep production in Brazil. Appl. Geogr. 2013, 44, 172-181. [CrossRef]

17. McManus, C.; Barcellos, J.O.J.; Formenton, B.K.; Hermuche, P.M.; de Carvalho, O.A.; Guimarães, R.F.; Gianezini, M.; Dias, E.A.; Do Nascimento Lampert, V.; Zago, D.; et al. Dynamics of cattle production in Brazil. PLoS ONE 2016, 11, e0147138. [CrossRef] [PubMed]

18. Teixeira, R.F.A.P.; Bertella, M.A. Distribuição Espaço-Temporal da Produtividade Média do Café em Minas Gerais: 1997-2006. Anál. Econ. 2015, 33, 275-299.

19. Da Silva, G.J.C.; Souza, E.C.; Martins, H.E.D.P. Produção agropecuária em municípios de Minas Gerais (1996-2006): Padrões de distribuição, especialização e associação espacial. Rev. Econ. Sociol. Rural 2012, 50, 333-349. [CrossRef]

20. Wrublack, S.C.; Prudente, V.H.R.; Mercante, E.; Machado Coelho, S.R. Spatial distribution of Canola culture in the State of Paraná (Brazil) between the agricultural years of 2005 and 2009. Cienc. Investig. Agrar. 2013, 40, 523-535. [CrossRef]

21. Prudente, V.H.R.; Prado, M.L.; Silva, B.K.; Mercante, E.; Opazo, M.A.U. Análise Espacial da Produção de Soja no Estado do Paraná, durante as safras de 2003/2004 a 2007/2008. In Proceedings of the XV Simpósio Brasileiro de Sensoriamento Remoto-SBSR, Curitiba, Brazil, 30 April-5 March 2011; pp. 647-652.

22. Rodrigues, M.A.; de Moraes, M.L.; Bacha, C.J.C. A expansão da cana-de-açúcar entre 1973 e 2007: Uma análise espacial. In Proceedings of the Congresso da Sociedade Brasileira de Economia, Administração e Sociologia Rural, Vitória, Brazil, 22-25 July 2012.

23. Moran, P.A.P. Notes on continuous stochastic phenomena. Biometrika 1950, 37, 17-23. [CrossRef] [PubMed] 
24. Anselin, L. The Moran Scatterplot as an ESDA tool to assess local instability in spatial association. In Spatial Analytical Perspectives on GIS; Taylor \& Francis: London, UK; Bristol, UK; Philadelphia, PA, USA, 1996; Volume 111, pp. 111-125.

25. Almeida, E. Econometria Espacial Aplicada, 1st ed.; Alinea: Campinas, Brazil, 2012.

26. Nelson, T.A.; Boots, B. Detecting spatial hot spots in landscape ecology. Ecography 2008, 31, 556-566. [CrossRef]

27. Hermuche, P.M.; Maranhão, R.L.A.; Guimarães, R.F.; de Carvalho Júnior, O.A.; Gomes, R.A.T.; Paiva, S.R.; McManus, C. Dynamics of sheep production in Brazil. ISPRS Int. J. Geo-Inf. 2013, 2, 665-679. [CrossRef]

28. Porter, M.E. Competitive advantage, agglomeration economies, and regional policy. Int. Reg. Sci. Rev. 1996, 19, 85-90.

29. Cho, S.; Newman, D.H. Spatial analysis of rural land development. For. Policy Econ. 2005, 7, 732-744. [CrossRef]

30. Cho, S.; Chen, Z.; Yen, S.T.; English, B.C. Spatial variation of output-input elasticities: Evidence from Chinese county-level agricultural production data. Pap. Reg. Sci. 2007, 86, 139-157. [CrossRef]

31. Cho, S.; Chen, Z.; Poudyal, N.C. Spatial structure of agricultural production in China. Appl. Econ. 2010, 42, 2031-2040. [CrossRef]

32. Yu, T.H.E.; Cho, S.; Koç, A.A.; Bölük, G.; Kim, S.G.; Lambert, D.M. Evaluating spatial and temporal variation in agricultural output elasticities in Turkey. Agric. Econ. 2014, 45, 279-290. [CrossRef]

33. Silva, M.G.; Arf, O.; Teodoro, P.E. Nitrogen topdressing and application ways of fluazifop-p-butyl + fomesafen in weed control and agronomic performance of common bean. An. Acad. Bras. Cienc. 2015, 87, 2301-2307. [CrossRef] [PubMed]

34. Fu, W.J.; Jiang, P.K.; Zhou, G.M.; Zhao, K.L. Using Moran's I and GIS to study the spatial pattern of forest litter carbon density in a subtropical region of southeastern China. Biogeosciences 2014, 11, 2401-2409. [CrossRef]

35. Baker, S.R.; Davis, S.J.; Dashkeyev, V.; Deriy, O.; Dinh, E.; Ezure, Y.; Gong, R.; Jindal, S.; Kim, R.; Klosin, S.; et al. Measuring economic policy uncertainty. Q. J. Econ. 2016, 131, 1593-1636. [CrossRef]

36. Wander, A.E. Produção e consumo de feijão no Brasil, 1975-2005. Inf. Econ. 2007, 37, 7-21.

37. De Oliveira, S.N.; de Carvalho Júnior, O.A.; Gomes, R.A.T.; Guimarães, R.F.; McManus, C.M. Landscape-fragmentation change due to recent agricultural expansion in the Brazilian Savanna, Western Bahia, Brazil. Reg. Environ. Chang. 2017, 17, 411-423. [CrossRef]

38. De Oliveira, S.N.; de Carvalho Júnior, O.A.; Gomes, R.A.T.; Guimarães, R.F.; McManus, C.M. Deforestation analysis in protected areas and scenario simulation for structural corridors in the agricultural frontier of Western Bahia, Brazil. Land Use Policy 2017, 61, 40-52. [CrossRef]

39. Chagas, J.M.; Ferreira, A.C.D.B.; Paula Júnior, T.J.; Chagas, R.B. Produtividade e custo de produção do feijão em diferentes níveis tecnológicos. Inf. Agropecu. 2004, 25, 7-12.

40. Barreto, R.C.S.; Almeida, E. A contribuição da pesquisa para convergência e crescimento da renda agropecuária no Brasil. Rev. Econ. Sociol. Rural 2009, 47, 719-737. [CrossRef]

41. Didonet, A.D.; Silva, S.C. Elementos climáticos e produtividade do feijoeiro. Inf. Agropecu. 2004, 25, 13-19.

42. Didonet, A.D. Pesquisa e desenvolvimento em agricultura familiar na Embrapa Arroz e Feijão. Embrapa Arroz Feijão 2004, 166, 1-16.

43. Crestana, S.; Alves, E. A Embrapa e o Agronegócio. In O desafio da China e da Índia: A resposta do Brasil; Velloso, J.P.R., Ed.; José Olympio: Rio de Janeiro, Brazil, 2005; pp. 297-314.

(C) 2017 by the authors. Licensee MDPI, Basel, Switzerland. This article is an open access article distributed under the terms and conditions of the Creative Commons Attribution (CC BY) license (http:/ / creativecommons.org/licenses/by/4.0/). 